\title{
Retention of proteins and minerals after cooking in cowpea genotypes ${ }^{1}$
}

\author{
Danillo Olegário Matos da Silva², Carlos Antonio Fernandes Santos ${ }^{3}$, \\ Sirando Lima Seido ${ }^{4}$, Washington Carvalho Pacheco Coelho ${ }^{2}$, Deisy Aiane Lima de Aquino ${ }^{2}$
}

\section{ABSTRACT}

Cowpea is a tolerant crop to water deficit, with moderate protein and mineral contents, as well as fast cooking, which are important requirements for semi-arid regions. This study aimed to evaluate the retention of total proteins and minerals after cooking in cowpea genotypes, in order to select those that best preserve these nutrients contents. Twenty-four genotypes were evaluated, being ten lines, five commercial cultivars and nine landraces maintained by farmers. Cooking had a reduced effect on the contents of protein, potassium, calcium, iron and zinc in cowpea grains, with significant effects only in a few genotypes. A significant and positive correlation was observed only for grain yield $\mathrm{x}$ zinc content and protein content $x$ cooking time. The line CPCR3F6L17 presented a high grain yield and high levels of protein, potassium, iron and zinc after cooking, showing to be a promising option for the studied region.

KEYWORDS: Vigna unguiculata; nutrient content; thermal processing.

\section{INTRODUCTION}

Cowpea [Vigna unguiculata (L.) Walp.] is widely cultivated in semi-arid regions, because of its tolerance to water stress and low soil fertility, in addition to its grain yield capacity, when compared with other legume species (Silva et al. 2016).

In many African, Asian and South American countries, cowpea is the main dietary supply of vegetables for populations from semi-arid regions with a great tradition of consumption (Freire Filho 2011). In the Brazilian semi-arid region, cowpea has become one of the main social and economic alternatives for the rural population, and its cultivation has expanded to other regions, reaching

\section{RESUMO}

Retenção de proteínas e minerais após a cocção em genótipos de feijão-caupi

O feijão-caupi é uma cultura tolerante ao déficit hídrico, com teores moderados de proteínas e minerais e rápida cocção, requisitos importantes para regiões semiáridas. Objetivou-se avaliar a retenção de proteínas totais e minerais após a cocção, em genótipos de feijão-caupi, a fim de selecionar os que melhor preservem os teores desses nutrientes. Foram avaliados 24 genótipos, sendo dez linhagens, cinco cultivares comerciais e nove variedades mantidas por agricultores. A cocção teve efeito reduzido nos teores de proteína, potássio, cálcio, ferro e zinco, nos grãos de feijão-caupi, com efeitos significativos em poucos genótipos. Foi observada correlação significativa e positiva apenas para produção de grãos $\mathrm{x}$ teor de zinco e proteínas $\mathrm{x}$ tempo de cocção. A linhagem CPCR3F6L17 obteve alta produtividade de grãos e elevados teores de proteína, potássio, ferro e zinco, após a cocção, mostrando-se promissora para a região estudada.

Palavras-chave: Vigna unguiculata; teor de nutrientes; processamento térmico.

new domestic and international markets (Oliveira et al. 2010).

Due to its high grain yield and higher nutrient content, if compared with crops traditionally grown by small farmers in the semi-arid regions, cowpea has been a good option for the diet of several populations. Some studies have proved that cowpea presents a significant variability of chemical composition in the grains, which allows the selection of genotypes with high nutritional contents (Santos \& Boiteux 2013, Silva et al. 2016, Silva \& Santos 2016).

The accumulation and retention of some minerals are influenced by the interaction of different factors, such as varieties, environmental conditions, part of the grain where the mineral is concentrated

1. Manuscript received in Jun./2017 and accepted for publication in Sep./2017 (http://dx.doi.org/10.1590/1983-40632016v4747261).

2. Universidade Estadual de Feira de Santana, Feira de Santana, BA, Brasil.E-mails: danilloolegario@hotmail.com, washington_cpc@hotmail.com, deisylima_17@hotmail.com.

3. Empresa Brasileira de Pesquisa Agropecuária (Embrapa Semiárido), Petrolina, $\mathrm{PE}$, Brasil.E-mail: carlos-fernandes.santos@embrapa.br. 4. Universidade Federal Rural de Pernambuco, Recife, PE, Brasil.E-mail: siroseido@hotmail.com. 
and minerals solubility during immersion and cooking (Bassinello 2009). Pereira et al. (2014) evaluated five cowpea cultivars for nutrient retention in normal and pressure cookers, with and without grain immersion, and observed different responses of cultivars, regarding iron and zinc contents after cooking. In another study, Pereira et al. (2016) evaluated the bioaccessibility of these nutrients and highlighted the importance of determining the actual percentage of absorption and efficient strategies for low-income populations to have access to foods with high nutritional levels.

Another important factor in the accumulation and retention of some minerals is the high concentrations of tannins and phytates present in the grains. Carvalho et al. (2012) emphasize that the presence of phytates and tannins in plant fibers may negatively influence the availability of iron and zinc, as well as the cooking time. Lazarte et al. (2015) observed that phytate levels promoted a significant decrease in the availability of calcium, iron and zinc, and suggested the immersion and fermentation of grains to improve the nutrient availability. Hemalatha et al. (2007) stated that tannins do not significantly influence iron and zinc contents in cereals and legumes.

The lack of protein and minerals in food has negatively contributed to public health, affecting almost half of the world's population, especially children, adolescents and pregnant women (Kraemer \& Zimmermann 2007). Cowpea presents a great variability in the chemical composition of grains, what enables the selection of genotypes with high nutritional concentration of iron, zinc, calcium and potassium (Silva \& Santos 2016 and 2017). Iron is essential for basic cellular functions in all body tissues (Rios et al. 2011). Zinc is the cofactor of more than 300 enzymes necessary for growth and development (Shankar \& Prasad 1998). Calcium is important for muscle contractions and the nervous system (McDowell 1992). Potassium is the third most abundant mineral in the human body and is essential for human life (United Kingdom 1991).

The Food and Agricultural Organization of the United Nations considers cowpea as one of the best options to increase protein supply, due to its low production cost (Grangeiro et al. 2005). The selection of new cowpea cultivars with high protein and mineral contents in the grains is crucial for human health, especially in the diet of the low-income population in the semi-arid regions. Cowpea grains present a fast cooking time, which is an important requirement for those suffering from shortage of fuel and other natural resources (Ehlers \& Hall 1997). However, the way nutrients are used by the human body may be compromised due to several factors. According to Ramírez-Cárdenas et al. (2008), the main problems are the high content of antinutritional factors, such as tannins and phytates, and the processing type, such as threshing, immersion and cooking.

The cooking time is a primary factor in the choice of a cultivar by consumers who aim to save time in meal preparation. In addition, prolonged cooking time should be avoided, as it may cause structural changes at the cellular level, reducing the availability of nutrients (Pujola et al. 2007). Mota et al. (2016) evaluated cooking methods in amaranth, wheat and quinoa, and concluded that estimates of mineral intake should be based on data obtained from cooked foods. Few studies have reported the effect of cooking on protein and mineral contents in cowpea, following the pioneering research of Pereira et al. (2014).

The present study aimed to evaluate the total proteins and minerals retention after cooking in cowpea genotypes, in order to select those that best preserve the nutrients content.

\section{MATERIAL AND METHODS}

Twenty-four cowpea genotypes were evaluated, being ten lines from the Embrapa Semiárido, five commercial cultivars and nine local varieties collected from farmers in Juazeiro (Bahia state) and Petrolina (Pernambuco state), Brazil (Table 1). The experiments were conducted in 2014-2, in an experimental field of Mandacaru, in Juazeiro. The experiment consisted of a completely randomized block design, with three replications, in $2.0 \mathrm{~m} \times 3.0 \mathrm{~m}$ plots, spaced $1.0 \mathrm{~m}$ between rows and $0.1 \mathrm{~m}$ between plants.

Green grains were cooked using a Mattson cooker, a quick and practical apparatus to evaluate grain cooking time (Yeung et al. 2009). Groups of 25 grains were randomly selected from each treatment for evaluation with three replications, totaling 75 grains. The cooking time corresponded to the dropping of the twenty-third plunger of the Mattson grain cooker. The plunger of the apparatus exerts a pressure that corresponds to the tactile method for determining cooking times (by smashing the bean grain between the fingers). According to Proctor \& Watts (1987), the dropping time of 23 of the 25 
plungers, which represents $92 \%$ of cooked grains, should be used as the optimum cooking time. This provided an acceptable cooking texture and the preferred degree of softness in sensorial analyses, in addition to a better discrimination between samples.

Raw and cooked grains were ground in a MA 630/1 mill (Marconi, Brazil), to obtain a fine flour from each sample, for the quantification of total proteins and minerals. The quantification of total proteins in dry beans was performed by the chemical method of Kjeldhal (AOAC 1995). The flour was analyzed in duplicates for each sample (AOAC 1995). The percentage of nitrogen was calculated using the formula: $\% \mathrm{~N}=0.14 *$ correction factor of the $\mathrm{HCl}$ solution * volume used in the $\mathrm{HCl}$ titration. Protein was determined by multiplying the percentage of nitrogen by the 6.25 factor.

Two extracts of raw and cooked grains were prepared for the mineral quantification: 1) extract A for iron and zinc: after the cooling of the digestion tubes, $49 \mathrm{~mL}$ of deionized and distilled water were added, and the $\mathrm{Fe}$ and $\mathrm{Zn}$ contents were determined in a flame atomic absorption spectrophotometer (Varian); 2) extract B for potassium and calcium: $1 \mathrm{~mL}$ of the extract A was transferred to a $50 \mathrm{~mL}$ Becker, identified according to the protocol number of the samples, the volume was completed with $49 \mathrm{~mL}$ of $0.1 \%$ lanthanum oxide and the samples of extract B were used for potassium quantification, using a flame photometer (MicroNal), while the calcium was determined in a flame atomic absorption spectrophotometer (Varian). Results were expressed as $\mathrm{g} \mathrm{kg}^{-1}$ of grain dry matter for potassium and calcium and as mg kg-1 for iron and zinc.

Analyses of simple and factorial variance were performed using the GLM procedure of the SAS software (SAS 1989) for grain yield, cooking time, total proteins and minerals. Grain yield was corrected by the method of covariance with the mean plant stand of the plots (Vencovsky \& Barriga 1992), using

Table 1. Averages of yield, cooking time and protein, potassium, calcium, iron and zinc contents of 24 cowpea genotypes evaluated before $(\mathrm{BC})$ and after $(\mathrm{AC})$ cooking.

\begin{tabular}{|c|c|c|c|c|c|c|c|c|c|c|}
\hline \multirow{2}{*}{ Treatment } & \multirow{2}{*}{$\frac{\text { Yield }}{\mathrm{kg} \mathrm{ha}^{-1}}$} & \multirow{2}{*}{$\frac{\text { Cooking time }}{\min }$} & \multicolumn{3}{|c|}{ Protein $(\%)$} & \multirow{2}{*}{$\frac{\text { Potassium }}{\mathrm{g} \mathrm{kg}^{-1}}$} & \multirow{2}{*}{$\frac{\text { Iron }}{\mathrm{mg} \mathrm{kg}^{-1}}$} & \multicolumn{3}{|c|}{ Zinc $\left(\mathrm{mg} \mathrm{kg}^{-1}\right)$} \\
\hline & & & $\mathrm{BC}$ & $\mathrm{AC}$ & $\mathrm{DM}$ & & & $\mathrm{BC}$ & $\mathrm{AC}$ & $\mathrm{DM}$ \\
\hline PD1_Petrolina-PE & $2,079.6 \mathrm{a}$ & $13.2 \mathrm{~b}$ & $27.8 \mathrm{a}$ & $27.7 \mathrm{a}$ & ns & $11.8 \mathrm{~b}$ & $53.9 \mathrm{~b}$ & $32.5 \mathrm{~b}$ & $34.2 \mathrm{a}$ & ns \\
\hline PD2_Juazeiro-BA & $1,548.4 \mathrm{~b}$ & $10.7 \mathrm{a}$ & $23.8 \mathrm{~b}$ & $21.8 \mathrm{c}$ & ns & $10.6 \mathrm{~b}$ & $55.1 \mathrm{~b}$ & $37.2 \mathrm{~b}$ & $36.1 \mathrm{a}$ & ns \\
\hline PD3_Juazeiro-BA & $1,676.1 \mathrm{~b}$ & $11.5 \mathrm{a}$ & $24.7 \mathrm{~b}$ & $25.8 \mathrm{~b}$ & $\mathrm{~ns}$ & $11.4 \mathrm{~b}$ & $49.8 \mathrm{~b}$ & $32.4 \mathrm{~b}$ & $32.5 \mathrm{~b}$ & ns \\
\hline PD4_Juazeiro-BA & $1,515.1 \mathrm{~b}$ & $11.3 \mathrm{a}$ & $26.2 \mathrm{~b}$ & $26.9 \mathrm{a}$ & ns & $15.4 \mathrm{a}$ & $57.4 \mathrm{a}$ & $40.2 \mathrm{a}$ & $35.1 \mathrm{a}$ & ns \\
\hline PD5_Juazeiro-BA & $1,259.8 \mathrm{~b}$ & $10.9 \mathrm{a}$ & $24.9 \mathrm{~b}$ & $25.5 \mathrm{~b}$ & ns & $11.1 \mathrm{~b}$ & $54.4 \mathrm{~b}$ & $32.4 \mathrm{~b}$ & $34.6 \mathrm{a}$ & $*$ \\
\hline PD6_Petrolina-PE & $2,053.5 \mathrm{a}$ & $10.7 \mathrm{a}$ & $24.5 \mathrm{~b}$ & $28.4 \mathrm{a}$ & $*$ & $10.4 \mathrm{~b}$ & $54.2 \mathrm{~b}$ & $30.5 \mathrm{~b}$ & $36.6 \mathrm{a}$ & ns \\
\hline PD7_Petrolina-PE & $1,640.0 \mathrm{~b}$ & $11.6 \mathrm{a}$ & $26.5 \mathrm{~b}$ & $26.3 \mathrm{~b}$ & ns & $12.0 \mathrm{~b}$ & $53.9 \mathrm{~b}$ & $35.2 \mathrm{~b}$ & $31.6 \mathrm{~b}$ & $* *$ \\
\hline PD8_Petrolina-PE & $922.5 \mathrm{~b}$ & $14.9 \mathrm{~b}$ & $27.5 \mathrm{a}$ & $25.6 \mathrm{~b}$ & ns & $11.7 \mathrm{~b}$ & $54.4 \mathrm{~b}$ & $37.1 \mathrm{~b}$ & $36.2 \mathrm{a}$ & ns \\
\hline PD9_Petrolina-PE & $1,340.3 \mathrm{~b}$ & $10.8 \mathrm{a}$ & $24.4 \mathrm{~b}$ & $25.2 \mathrm{~b}$ & ns & $11.2 \mathrm{~b}$ & $48.0 \mathrm{~b}$ & $30.3 \mathrm{~b}$ & $30.3 \mathrm{c}$ & ns \\
\hline P209 & $2,316.6 \mathrm{a}$ & $13.4 \mathrm{~b}$ & $24.8 \mathrm{~b}$ & $26.4 \mathrm{~b}$ & ns & $12.5 \mathrm{~b}$ & $59.4 \mathrm{a}$ & $41.8 \mathrm{a}$ & $36.0 \mathrm{a}$ & ns \\
\hline PC951015D01E & $2,358.7 \mathrm{a}$ & $11.7 \mathrm{a}$ & $27.0 \mathrm{a}$ & $25.7 \mathrm{~b}$ & $* *$ & $11.7 \mathrm{~b}$ & $63.0 \mathrm{a}$ & $34.8 \mathrm{~b}$ & $34.6 \mathrm{a}$ & ns \\
\hline PC950409D02E & $2,480.8 \mathrm{a}$ & $9.6 \mathrm{a}$ & $28.6 \mathrm{a}$ & $24.5 \mathrm{~b}$ & ns & $13.4 \mathrm{a}$ & $52.2 \mathrm{~b}$ & $31.7 \mathrm{~b}$ & $32.8 \mathrm{~b}$ & ns \\
\hline PC951016D01E & $1,984.1 \mathrm{a}$ & $15.0 \mathrm{~b}$ & $24.6 \mathrm{~b}$ & $25.8 \mathrm{~b}$ & ns & $13.9 \mathrm{a}$ & $53.1 \mathrm{~b}$ & $31.2 \mathrm{~b}$ & $32.8 \mathrm{~b}$ & ns \\
\hline CPCR3F6L15 & $1,940.4 \mathrm{~b}$ & $12.1 \mathrm{a}$ & $26.1 \mathrm{~b}$ & $25.0 \mathrm{~b}$ & ns & $14.0 \mathrm{a}$ & $69.0 \mathrm{a}$ & $35.4 \mathrm{~b}$ & $33.9 \mathrm{a}$ & ns \\
\hline CPCR3F6L17 & $2,374.3 \mathrm{a}$ & $13.9 \mathrm{~b}$ & $30.7 \mathrm{a}$ & $28.1 \mathrm{a}$ & ns & $12.5 \mathrm{~b}$ & $60.2 \mathrm{a}$ & $36.9 \mathrm{~b}$ & $35.0 \mathrm{a}$ & ns \\
\hline $\mathrm{C} 2 \mathrm{M}$ & $1,108.9 \mathrm{~b}$ & $10.9 \mathrm{a}$ & $28.6 \mathrm{a}$ & $27.4 \mathrm{a}$ & ns & $11.0 \mathrm{~b}$ & $52.0 \mathrm{~b}$ & $29.9 \mathrm{~b}$ & $28.7 \mathrm{c}$ & ns \\
\hline $\mathrm{C} 2 \mathrm{~S}$ & $1,325.3 \mathrm{~b}$ & $11.9 \mathrm{a}$ & $23.7 \mathrm{~b}$ & $26.9 \mathrm{a}$ & $*$ & $10.5 \mathrm{~b}$ & $56.4 \mathrm{~b}$ & $35.8 \mathrm{~b}$ & $31.4 \mathrm{~b}$ & ns \\
\hline $\mathrm{C} 1 \mathrm{~J}$ & $1,343.1 \mathrm{~b}$ & $11.3 \mathrm{a}$ & $25.4 \mathrm{~b}$ & $25.5 \mathrm{~b}$ & ns & $12.3 \mathrm{~b}$ & $52.7 \mathrm{~b}$ & $37.7 \mathrm{~b}$ & $29.7 \mathrm{c}$ & ns \\
\hline C3Q & $1,409.7 \mathrm{~b}$ & $16.6 \mathrm{~b}$ & $26.0 \mathrm{~b}$ & $28.1 \mathrm{a}$ & ns & $10.5 \mathrm{~b}$ & $60.4 \mathrm{a}$ & $32.6 \mathrm{~b}$ & $33.0 \mathrm{~b}$ & ns \\
\hline BRS Acauã & $1,440.2 \mathrm{~b}$ & $15.4 \mathrm{~b}$ & $28.3 \mathrm{a}$ & 28.9 a & ns & $12.3 \mathrm{~b}$ & $55.8 \mathrm{~b}$ & $34.4 \mathrm{~b}$ & $34.3 \mathrm{a}$ & ns \\
\hline BRS Guariba & $1,716.6 \mathrm{~b}$ & $14.7 \mathrm{~b}$ & $27.0 \mathrm{a}$ & $26.1 \mathrm{~b}$ & ns & $11.0 \mathrm{~b}$ & $58.9 \mathrm{a}$ & $33.1 \mathrm{~b}$ & $34.0 \mathrm{a}$ & ns \\
\hline BRS Marataoã & $1,764.9 \mathrm{~b}$ & $14.3 \mathrm{~b}$ & $25.0 \mathrm{~b}$ & $26.8 \mathrm{a}$ & ns & $13.0 \mathrm{a}$ & $61.3 \mathrm{a}$ & $35.5 \mathrm{~b}$ & $35.2 \mathrm{a}$ & ns \\
\hline BRS Pujante & $1,540.1 \mathrm{~b}$ & $11.8 \mathrm{a}$ & $26.5 \mathrm{~b}$ & $24.2 \mathrm{~b}$ & ns & $11.5 \mathrm{~b}$ & $62.1 \mathrm{a}$ & $32.9 \mathrm{~b}$ & $32.9 \mathrm{~b}$ & ns \\
\hline BRS Rouxinol & $1,723.3 \mathrm{~b}$ & $13.5 \mathrm{~b}$ & $28.0 \mathrm{a}$ & $26.0 \mathrm{~b}$ & ns & $11.3 \mathrm{~b}$ & $59.4 \mathrm{a}$ & $35.3 \mathrm{~b}$ & $33.7 \mathrm{a}$ & ns \\
\hline CV (\%) & 18.6 & 21.3 & 5.4 & 4.9 & & 10.3 & 8.36 & 7.3 & 5.5 & \\
\hline
\end{tabular}


the SAS software. The Scott-Knott test was applied at $5 \%$ for the genotypes averages, and the Student t-test was used for differences between averages before and after cooking. Pearson correlation coefficients were estimated among all variables.

\section{RESULTS AND DISCUSSION}

Genotypes were significantly different for total protein, potassium, iron and zinc contents $(\mathrm{p}<0.01)$, indicating the existence of variability among them and the possibility of obtaining a selection gain (Table 2). Cooking had a significant effect on calcium, iron and zinc contents $(\mathrm{p}<0.05)$, and no differences were observed for protein and potassium contents (Table 2). The genotype $\mathrm{x}$ cooking time interaction was observed only for total protein and zinc contents $(\mathrm{p}<0.05)$, indicating that the genotypes had a different response to cooking only in these two variables. According to Ramírez-Cárdenas et al. (2008), the proteins and minerals availability may be compromised because of the high content of antinutritional factors, such as phytates, tannins and fibers, which negatively influence the protein and minerals content, besides the processing, such as cooking.

In spite of the little difference between the overall averages of total proteins and minerals before and after cooking, a slight reduction was observed in the nutritional content of cowpea grains, being minimal for proteins $(0.4 \%)$ and more pronounced for iron (3.1\%) (Table 2). Similar results were reported by ElMaki et al. (2007), who evaluated the effects of cooking, with and without immersion, on mineral contents and antinutritional factors.

Genotypes differed for grain yield $(\mathrm{p}<0.01)$, ranging $922.5-2,480.8 \mathrm{~kg} \mathrm{ha}^{-1}$ between the genotypes PD8 and PC950409D02E, respectively (Table 1).
Genotypes also varied in relation to the cooking time, with the shortest time of 9.6 min observed for the line PC950409D02E, and the longest time of 16.6 min reported for line C3Q (Table 1). Possibly, the short cooking time of cowpea grains provided a smaller reduction in the nutritional contents, when comparing raw and cooked grains.

Genotypes showed variability for protein contents $(p<0.01)$ before and after cooking, with an average of approximately $26 \%$. The highest values were observed for the genotypes PD6, CPCR3F6L17, C3Q and BRS Acauã (Table 1). Genotypes also presented differences for potassium content $(\mathrm{p}<0.01)$, with an average of approximately $12 \mathrm{~g} \mathrm{~kg}^{-1}$. The genotype PD4 presented the highest average. For calcium contents, the variability among genotypes was non-significant. For the iron and zinc contents, the variability between genotypes averages was significant $(\mathrm{p}<0.01)$, with $56.5 \mathrm{mg} \mathrm{kg}^{-1}$ and $34 \mathrm{mg} \mathrm{kg}^{-1}$, respectively. The line CPCR3F6L15 stood out for its high iron content after cooking (70.8 $\mathrm{mg} \mathrm{kg}^{-1}$ ) (Table 1).

Genotypes were not different before and after cooking for protein content, by the $\mathrm{t}$ test, except for the genotypes PD6, PC951015D01E and C2S, whose mean values decreased or increased (Table 1). Cooking influenced only the genotype PD5 for zinc content, with no effects observed for iron in all the genotypes evaluated in this study (Table 1). Significant differences were reported by Mota et al. (2016), who evaluated minerals in amaranth, wheat and quinoa after cooking, as well as by Pereira et al. (2016), who evaluated the effect of cooking methods on iron and zinc contents in cowpea cultivars.

The genotypes BRS Acauã, PD6, C3Q and CPCR3F6L17 presented the highest protein contents after cooking (28.1-28.9\%) (Table 1). The highest

Table 2. Mean square for yield, cooking time, protein, potassium, calcium, iron and zinc contents in cowpea genotypes.

\begin{tabular}{|c|c|c|c|c|c|c|c|c|}
\hline \multirow{2}{*}{ Source of variation } & \multirow{2}{*}{$\mathrm{DF}$} & \multicolumn{7}{|c|}{ Mean square } \\
\hline & & Yield & Cooking time & Protein & Potassium & Calcium & Iron & Zinc \\
\hline Genotype (G) & 23 & $356,235^{\text {ns }}$ & $13.7^{*}$ & $8.34 * *$ & $7.06 * *$ & $0.04^{\mathrm{ns}}$ & $102.30 * *$ & $21.97 * *$ \\
\hline Cooking (C) & 1 & - & - & $0.28^{\mathrm{ns}}$ & $2.65^{\mathrm{ns}}$ & $0.52 * *$ & $90.00 *$ & $24.40 *$ \\
\hline $\mathrm{G} \times \mathrm{C}$ & 23 & - & - & $4.34 * *$ & $2.40^{\text {ns }}$ & $0.03^{\text {ns }}$ & $32.96^{\mathrm{ns}}$ & $10.00 *$ \\
\hline Error & 64 & 212,156 & 6.7 & 1.79 & 1.51 & 0.03 & 22.33 & 4.87 \\
\hline CV (\%) & & 26.7 & 21.3 & 5.09 & 10.33 & 13.34 & 8.36 & 6.54 \\
\hline Mean & & & & $\%$ & $-\mathrm{g}$ & -1 & $-\mathrm{mg}$ & \\
\hline Before cooking & & & & 26.3 & 12.1 & 1.4 & 57.4 & 34.5 \\
\hline After cooking & & & & 26.2 & 11.9 & 1.2 & 55.7 & 33.6 \\
\hline
\end{tabular}

**,* and ${ }^{\mathrm{ns}}$ : significant at $1 \%, 5 \%$ and non-significant, respectively, by the $\mathrm{F}$ test. 
potassium contents after cooking were observed in the genotype PD4 and the cultivar BRS Marataoã, while the highest iron and zinc contents after cooking were observed for the lines CPCR3F6L15 and PD6, respectively (Table 1). The highest calcium content after cooking was observed for BRS Acauã (Table 1).

Among the nine evaluated genotypes, only PD1 and PD6s, both from Petrolina, presented grain yields higher than the overall average. These genotypes also showed protein, calcium and zinc contents after cooking superior to the overall average (Table 1). The lines P209, PC951015D01E, PC950409D02E and CPCR3F6L17 stood out for their high grain yield, being $31 \%$ higher than the most productive cultivar (BRS Marataoã) and $35 \%$ higher than the overall average of the experiment (Table 1). The line PC951015D01E presented a high grain yield, but showed a significant reduction in the protein content after cooking (Table 1). The line CPCR3F6L17, with the highest grain yield among all the evaluated genotypes, also presented nutritional contents above the overall averages for protein, potassium, iron and zinc contents after cooking (Table 1).

A significant and positive correlation was observed only between grain yield and zinc content, as well as between protein content and cooking time. The protein content increased with the increase of cooking time (Table 3). Santos \& Boiteux (2013) reported correlations between grain yield and iron content, when evaluating protein and mineral contents in 87 cowpea genotypes, and did not observe a significant correlation between the protein content and the other variables.

Except for the line CPCR3F6L17, which presented the highest averages for grain yield and protein content, the lines with the highest nutritional contents were not the same as those with the highest grain yields. The results observed in this study indicate difficulties for selecting lines that combine high grain yields and high protein and mineral contents. Similar results were reported by Silva et al. (2016), who analyzed the protein content in 44 cowpea genotypes. An alternative to circumvent the limits imposed by the association between these two variables is the selection of intermediate or aboveaverage values.

In the northeast of Brazil, the cowpea production presented an annual average of $426,367 \mathrm{t}$, in 2010, with a great superiority in relation to other producing regions, but with the lowest average yield of $330 \mathrm{~kg} \mathrm{ha}^{-1}$ (Freire Filho 2011). However, this value does not reflect the genetic potential of the improved cultivars. In the present study, the lines CPCR3F6L17, PC951015D01E, PC950409D02E and P209 presented grain yields above $2,300 \mathrm{~kg} \mathrm{ha}^{-1}$ (Table 1). The literature reports yields of cowpea above $3,000 \mathrm{~kg} \mathrm{ha}^{-1}$ under irrigated conditions (Bezerra 1997).

The low production in this region is mainly due to the form of cultivation, carried out predominantly by small farmers, with lack of technology, such as pest and disease control and appropriate irrigation system. The average yield of cowpea genotypes used by farmers was approximately $15 \%$ lower than that of improved cultivars and lines (Table 1).

The selection of productive cowpea cultivars with low cooking time, biofortified, with high protein and mineral contents, adapted to various cultivation environments, and which are available to farmers and consumers, is increasingly needed. The line CPCR3F6L15 showed grain yield and potassium, calcium, iron and zinc contents above the overall average. The line CPCR3F6L17 showed a slightly longer cooking time, but presented a high grain yield and high protein, potassium, iron and zinc contents after cooking. Thus, CPCR3F6L17 was the most promising line for commercial cultivation and the one that better preserved the availability of nutrients.

Table 3. Pearson correlation coefficient among grain yield, cooking time and protein, potassium, calcium, iron and zinc contents in 24 cowpea genotypes evaluated after cooking.

\begin{tabular}{lcccccc}
\hline & Cooking & Protein & Potassium & Calcium & Iron & Zinc \\
\hline Yield & $0.17^{\mathrm{ns}}$ & $0.10^{\mathrm{ns}}$ & $0.17^{\mathrm{ns}}$ & $0.08^{\mathrm{ns}}$ & $0.25^{\mathrm{ns}}$ & $0.52^{* *}$ \\
Cooking time & & $0.45^{*}$ & $0.09^{\mathrm{ns}}$ & $0.16^{\mathrm{ns}}$ & $0.24^{\mathrm{ns}}$ & $0.26^{\mathrm{ns}}$ \\
Protein & & $-0.08^{\mathrm{ns}}$ & $0.14^{\mathrm{ns}}$ & $-0.15^{\mathrm{ns}}$ & $-0.01^{\mathrm{ns}}$ \\
Potassium & & & $-0.14^{\mathrm{ns}}$ & $0.19^{\mathrm{ns}}$ & $0.14^{\mathrm{ns}}$ \\
Calcium & & & & $-0.07^{\mathrm{ns}}$ & $0.19^{\mathrm{ns}}$ \\
Iron & & & & & & \\
\hline
\end{tabular}

**, $*$ and ${ }^{\mathrm{ns}}$ : significant at $1 \%$ and $5 \%$ and non-significant, respectively, by the $\mathrm{t}$ test. 


\section{CONCLUSIONS}

1. Cooking time, protein and mineral contents are affected by genotype;

2. Cooking reduces the calcium, iron and zinc contents in cowpea;

3. CPCR3F6L17 reached a high grain yield, as well as protein, potassium, iron and zinc contents, after cooking, being a promising line for cultivation in the regions of Petrolina and Juazeiro.

\section{REFERENCES}

ASSOCIATION OF OFFICIAL ANALYTICAL CHEMISTS (AOAC). Official methods of analysis. Arlington: AOAC, 1995.

BASSINELLO, P. Z. Qualidade nutricional, funcional e tecnológica do feijão. In: KLUTHCOUSKI, J.; STONE, L. F.; AIDAR, H. (Eds.). Fundamentos para uma agricultura sustentável, com ênfase na cultura do feijoeiro. Santo Antônio de Goiás: Embrapa Arroz e Feijão, 2009.

BEZERRA, A. A. C. Variabilidade e diversidade genética em caupi (Vigna unguiculata (L.) Walp.) precoce, de crescimento determinado e porte ereto e semiereto. 1997. 105 f. Dissertação (Mestrado em Agronomia) Universidade Federal Rural de Pernambuco, Recife, 1997.

CARVALHO, L. M. J. et al. Iron and zinc retention in common beans (Phaseolus vulgaris L.) after home cooking. Food \& Nutrition Research, v. 56, n. 1, p. 1-6, 2012.

EHLERS, J. D.; HALL, A. E. Cowpea (Vigna unguiculata L. Walp.). Field Crops Research, v. 53, n. 1-3, p. 187-204, 1997.

ELMAKI, H. B. et al. Content of antinutritional factors and $\mathrm{HCl}$-extractability of minerals from white bean (Phaseolus vulgaris) cultivars: influence of soaking and/or cooking. Food Chemistry, v. 100, n. 1, p. 362-368, 2007.

FREIRE FILHO, F. R. Feijão-caupi: produção, melhoramento genético, avanços e desafios. Teresina: Embrapa Meio-Norte, 2011.

GRANGEIRO, T. B. et al. Composição bioquímica da semente. In: FREIRE FILHO, F. R.; LIMA, J. A. A.; RIBEIRO, V. Q. (Eds.). Feijão-caupi: avanços tecnológicos. Brasília, DF: Embrapa Informação Tecnológica, 2005. p. 338-365.

HEMALATHA, S.; PLATEL, K.; KRISHNAPURA, S. Influence of heat processing on the bioaccessibility of zinc and iron from cereals and pulses consumed in India. Trace Elements in Medicine and Biology, v. 21, n. 1, p. 1-7, 2007.

KRAEMER, K.; ZIMMERMANN, M. B. Nutritional anemia. Basel: Sight and Life Press, 2007.
LAZARTE, C. E. et al. Phytate, zinc, iron and calcium content of common Bolivian food, and implications for mineral bioavailability. Journal of Food Composition and Analysis, v. 39, n. 1, p. 111-119, 2015.

MCDOWELL, L. R. Minerals in animal and human nutrition. San Diego: Academic Press, 1992.

MOTA, C. et al. The effect of cooking methods on the mineral content of quinoa (Chenopodium quinoa), amaranth (Amaranthus sp.) and buckwheat (Fagopyrum esculentum). Journal of Food Composition and Analysis, v. 49, n. 1, p. 57-64, 2016.

OLIVEIRA, O. M. S. et al. Período de convivência das plantas daninhas com cultivares de feijão-caupi em várzea no Amazonas. Planta daninha, v. 28, n. 3, p. 523-530, 2010.

PEREIRA, E. J. et al. Effects of cooking methods on the iron and zinc contents in cowpea (Vigna unguiculata) to combat nutritional deficiencies in Brazil. Food \& Nutrition Research, v. 58, n. 1, p. 1-7, 2014.

PEREIRA, E. J. et al. Effect of different home-cooking methods on the bioaccessibility of zinc and iron in conventionally bred cowpea (Vigna unguiculata L. Walp) consumed in Brazil. Food \& Nutrition Research, v. 60, n. 1, p. 1-6, 2016.

PROCTOR, J. R.; WATTS, B. M. Development of a modified Mattson bean cooker procedure based on sensory panel cookability evaluation. Canadian Institute of Food Science and Technology, v. 20, n. 1, p. 9-14, 1987.

PUJOLA, M.; FARRERAS, A.; CASAÑAS, F. Protein and starch content of raw, soaked and cooked beans (Phaseolus vulgaris L.). Food Chemistry, v. 102, n. 4, p. 1034-1041, 2007.

RAMÍREZ-CÁRDENAS L.; LEONEL, A. J.; COSTA, N. M. B. Efeito do processamento doméstico sobre o teor de nutrientes e de fatores antinutricionais de diferentes cultivares de feijão comum. Ciência e Tecnologia de Alimentos, v. 28, n. 1, p. 200-213, 2008.

RIOS, S. A. et al. Deficiências nutricionais e a biofortificação de alimentos. In: BORÉM, A.; RIOS, S. A. (Eds.). Milho biofortificado. Visconde do Rio Branco: Suprema, 2011.

SANTOS, C. A. F.; BOITEUX, L. S. Breeding biofortified cowpea lines for semi-arid tropical areas by combining higher seed protein and mineral levels, v. 12, n. 4, p. 67826789, 2013.

SAS INSTITUTE INC. SAS/STAT user's guide. Version 6. Cary: SAS Institute Inc., 1989.

SHANKAR, A. H.; PRASAD, A. S. Zinc and immune function: the biological basis of altered resistance to 
infection. American Journal of Clinical Nutrition, v. 68, n. 2, p. 475-635, 1998.

SILVA, D. O. M.; SANTOS, C. A. F. Adaptability and stability parameters for potassium and calcium contents and grain yield in cowpea lines. African Journal of Agricultural Research, v. 11, n. 36, p. 3366-3374, 2016.

SILVA, D. O. M.; SANTOS, C. A. F. Adaptability and stability parameters of iron and zinc concentrations and grain yield in cowpea lines in the Brazilian semiarid region. Crop Science, v. 57, n. 1, p. 1-10, 2017.

SILVA, D. O. M.; SANTOS, C. A. F.; BOITEUX, L. S. Adaptability and stability parameters of total seed yield and protein content in cowpea (Vigna unguiculata) genotypes subjected to semi-arid conditions. Australian Journal of Crop Science, v. 10, n. 8, p. 1164-1169, 2016.

UNITED KINGDOM. Department of Health. Committee on Medical Aspects of Food Policy. Dietary reference values for food energy and nutrients for the United Kingdom. London: HMSO, 1991.

VENCOVSKY, R.; BARRIGA, P. Genética biométrica no fitomelhoramento. Ribeirão Preto: Sociedade Brasileira de Genética, 1992.

YEUNG, H. et al. Rapid screening methods to evaluate cowpea cooking characteristics. Field Crops Research, v. 112, n. 2-3, p. 245-252, 2009. 